\title{
QUEEN'S
UNIVERSITY
BELFAST
}

\section{The 'Ordinariness of the EU's Foreign Policy Power: The Use of WTO Litigation as a Means to Export EU Norms, Values and Interests}

Melo Araujo, B. (2015). The 'Ordinariness of the EU's Foreign Policy Power: The Use of WTO Litigation as a Means to Export EU Norms, Values and Interests. Global Journal of Comparative Law, 4(2), 143-165. https://doi.org/10.1163/2211906X-00402001

\section{Published in:}

Global Journal of Comparative Law

\section{Document Version:}

Peer reviewed version

Queen's University Belfast - Research Portal:

Link to publication record in Queen's University Belfast Research Portal

Publisher rights

(c) 2015 Brill

\section{General rights}

Copyright for the publications made accessible via the Queen's University Belfast Research Portal is retained by the author(s) and / or other copyright owners and it is a condition of accessing these publications that users recognise and abide by the legal requirements associated with these rights.

Take down policy

The Research Portal is Queen's institutional repository that provides access to Queen's research output. Every effort has been made to ensure that content in the Research Portal does not infringe any person's rights, or applicable UK laws. If you discover content in the Research Portal that you believe breaches copyright or violates any law, please contact openaccess@qub.ac.uk. 
THE 'ORDINARINESS' OF THE EU'S FOREIGN POLICY POWER: THE USE OF WTO

LITIGATION AS A MEANS TO EXPORT EU NORMS, VALUES AND INTERESTS

\author{
Billy Melo Araujo, Queen's University Belfast \\ Billy.Melo_Araujo@qub.ac.uk
}

DRAFT - NOT FOR QUOTATION

To be published in The Global Journal of Comparative Law(2015) Vol 4 no.1

\begin{abstract}
:
The EU has historically been portrayed as a distinctive international actor both in terms of the norms and values it exports in context of its international relations and the manner in which it seeks to influence others. However, such claims to the EU's distinctiveness are increasingly being questioned. This article joins this chorus of voices arguing the non-distinctiveness of the EU's foreign policy power by focusing on a specific feature of the EU's external trade policy, the role of World Trade organization (WTO) dispute settlement in the EU's attempts to promote its interests, values and norms.
\end{abstract}

Key Words: EU; WTO; International relations

\title{
1. Introduction
}

Academic literature in the area of international relations has historically portrayed the European Union (EU) as a distinctive international actor. Popular conceptual frameworks for the EU's foreign policy action, such as 'Civilian Power Europe' and 'Normative Power Europe' contend that, unlike to traditional powers, the EU seeks to influence the international community through the dissemination of supposedly universal norms and value achieved by non-coercive and cooperative means. Such distinctiveness is, however, increasingly being contested by international relations and legal scholars; with some claiming that the EU's claims to universalism are based on a misguided conflation between European and universal norms, whilst others contend that the EU's power is purely a function of its economic power. 
This article joins the chorus of arguments that claim that the EU's foreign policy power is non-distinctive. It does so by focusing on an important feature of the EU's trade policy, the role of World Trade organization (WTO) dispute settlement in the EU's attempts to promote its interests and norms abroad. It argues, in particular, that WTO litigation is a key tool used by the EU not only to further its economic interests but also to promote regulatory positions and values that purely reflect its specific domestic preferences. In light of this, the article posits that the EU operates as a traditional and pragmatic foreign policy power, which is, inter alia, not adverse to promoting its self-interest.

Section II provides a descriptive overview of the various roles ascribed in the international relations theory to the EU as a foreign policy actor. Section III generally examines the dynamic relationship between the WTO litigation and EU domestic policy making and the extent to which WTO dispute settlement has become an important feature of the EU's attempts achieve its goals and influence international law. Section IV addresses two case studies illustrating how WTO dispute settlement is factored into the EU's internal and external regulatory policy making process in order to ensure that its interests and values are externalised. The first of these addresses the EU's current policy with respect to access to mineral resources, which led to two WTO rulings prohibiting import restrictions imposed by China on raw materials and rare earths. The second case study focuses on the EU's legislation banning trade in seal products - designed to compel States engaged in seal hunting to change their hunting practices in accordance with the EU's domestic preferences which was recently contested before the WTO judicature. Section V argues, in light of the case studies addressed in this article, that rather than shaping international law through non-coercive means and by promoting universal values and norms, the EU protects and projects its own interests and preferences by using its significant economic power to write the rules of the game in its favour.

\section{The EU's Identity as Foreign Policy Power}

The progressive rise of the EU (then the European Economic Community) as a global actor in the second half of the twentieth century brought into question many of the commonly held preconceptions as to how power and influence could be exercised in the context of international relations. Power-based politics (or 'hard power') based on military coercion and associated with nation-states such as the United States (US) did not adequately reflect the manner in which the EU has typically sought to influence the international community. Because of the absence of 
any military capability of note, economic policy, diplomacy and cooperation, rather than the military might and unilateral action which characterize the US's approach to foreign policy, have historically been the main tools used by the EU to further its interests abroad. The first attempt by international relations scholars to capture the distinctive identity of the EU drew a sharp contrast with the military and unilateral inclinations of the US. The EU was said to represent a new breed of international actor - a 'civilian power' ${ }^{\prime}$ based on the fulfillment of three fundamental criteria: “a) the acceptance of the necessity of cooperation with others in the pursuit of international objectives; b) the concentration on non-military power, primarily economic, means to secure national goals [....]; and c) a willingness to develop supranational superstructures to address critical issues of international management" ${ }^{\prime}$. Contrary to the US then, cooperation and deliberation were the means through which the EU would influence others, and it would do so by promoting international law and institutions

One of the criticisms aimed at this Civilian Power Europe was that it seeks to understand the EU's role in international relations through the prism of traditional Westphalian concepts concerning statehood and power. Underpinning the idea of Civilian Power Europe was the assumption that the EU was forced to find alternative means to wield power because it did not have the military capabilities of a nationState. However, ultimately, it operated very much like a traditional foreign policy power using a specific form of coercion (economic coercion) to pursue European interests abroad. Manners has argued that this assumption fundamentally misrepresents what the EU is and does in international relations. According to Manners, the distinctive nature of the EU's foreign policy can be attributed to the fact that the EU, itself, was the result of a desire from its Member States to move away from the nation-State paradigm and develop a supranational form of governance based on the promotion of universal norms and principles such as the respect of

1 J. Ruggie, “American Exceptionalism, Exemptionalism and Global Governance”, KSG Faculty Research Working Paper Series, February 2004 RWP04-006. Retrieved 28 April 2015 http://dx.doi.org/10.2139/ssrn.517642.

2 F. Duchene, "The European Community and the Uncertainties of Interdependence", in M. Kohnstamm and W. Hager (eds.) A Nation Writ Large? Foreign Policy Problems before the European Community (Basingstoke: MacMillan (1973).

${ }^{3}$ H. Maull, "Germany and Japan: The New Civilian Powers" Foreign Affairs 69(5) (1990) 91 at 92-93.

4 I. Manners, "Normative Power Europe: A Contradiction in Terms" Journal of Common Market Studies 40:2 (2002) 235 at 239. 
human rights, democracy and the rule of laws. It is this normative basis that compels the $\mathrm{EU}$ to act in a normative way in the context of its international relations (Normative Power Europe). According to Manners, the notion of Normative Power Europe is based on two key components of the EU's external action'. Firstly, there is the EU's commitment to disseminate a set of core norms (liberty, democracy, respect for human rights and the rule of law) and minor norms (social solidarity, antidiscrimination, sustainable development and good governance), which are reflective of its own identity rather than its self-interest. Secondly, the practices through which the EU promotes these norms must reflect the EU's fundamental values. For example, the EU should not coerce others into complying with its norms but rather engage with them in processes of deliberation and discussion, nor should it impose on third countries disciplines that it does not comply with itselfs. In other words, Normative Power is not simply a narrative a self-projection, whereby the EU exercises power by exporting its normative identity abroad, but also part of a longterm project to create a "more just, cosmopolitical world which empowers people in the actual conditions of their lives should", and which "must be based on more universally accepted values and principles that can be explained to both Europeans and non-European alike"

The obvious counterpoint to these conceptualizations of the EU as a foreign policy actor is the idea of the United States as an 'exceptionalist' (that is, as an international actor that sees itself as inherently superior and strives to ensure that international law reflects its values and norms) and as an exemptionalist (that is, an international actor that is above the strictures of international law meaning, for example, that the pursuance of national goals can fully justify recourse to unilateralism)". This would contrast with the idea of the EU as a civilian or normative actor promoting universal norms and values and attached to the pooling of sovereignty through international institutions. On this point, Manners posits that

5 Ibid at 241.

6 Ibid at 242-244.

7 I Manners, supra footnote 4 at243.

8 I Manners, "The Normative Ethics of the European Union" International Affairs 84: 1 (2008) 1 at 75-78.

${ }^{9}$ Ibid at 80.

10 Ibid.

11 J. Rubenfeld, "Unilateralism and Constitutionalism", New York University Law Review 79(6) (2004) 1971-2028; J. G. Ruggie, "Doctrinal Unilateralism and its Limits". In P. Forsythe, P. MacMahon and A. Wedeman (eds.) Doctrinal Unilateralism and its Limits : America and Global Governance in the New Century (New York: Routledge (2006)) 31-50. 
the absence of any claims to exceptionalism is a critical feature of the EU's normative action and that the supposedly 'universal norms' that the EU exports as well as its commitment to "non-hierarchical relationships" historical mistakes (e.g., colonialism) rather than a conviction based on any supposed innate superiority ${ }^{13}$. However, such distinctions are increasingly being contested with some arguing that exceptionalism, exemptionalism and unilateralism are not features that are unique to the US but are also verified in the EU's foreign policy practice ${ }^{i}$. A particular point of criticism relates to the suggestion under Normative Power Europe that the EU differs from other foreign policy powers insofar as its actions are driven by a propensity to promote fundamental norms and values that are not based on self-interest. This supposed virtuousness of the EU was recently rejected by De Burca's conceptualization the EU's 'governance mode' of foreign policy according to which the distinctiveness of the EU's foreign policy lies not in the substance of the policy but rather the manner in which such policy is conducted ${ }^{i s}$. De Burca argues that what truly sets apart the EU from other international actors is that in promoting its values and interest it has a clear preference "for the creation of stable, long-term, institutionalized relationships with other states and entities, and frequent use of regulatory frameworks involving common articulated goals and broad participation to regulate and coordinate policy externally". In that sense, De Burca's 'governance mode' conceptualization differs from Normative Power by avoiding any claim regarding the virtuousness of the EU's external action argung that the EU's default setting is to promote collective action and decision-making processes.

Yet, it is by no means evident that unilateralism plays second fiddle to collective or cooperative action in the context of the EU's external relations. In this respect, Bradford has highlighted the power that is wielded by the EU through the so-called "Brussels effect" ${ }_{16}$ which describes the EU's power to unilaterally regulate

12 I. Manners, "The European Union as a Normative Power: A Response to Thomas Diez", Millenium 35(1) (2006) 167 at 173.

13 Ibid.

${ }^{14}$ A. Bradford and E. Posner, Universal Exceptionalism in International Law" Harvard International Law Journal 52(1) (2011) 3-53. See also S. Safrin, "The Un-Exceptionalism of U.S. Exceptionalism, Vanderbilt Journal of Transnational Law 41(3) (2008) 1307.

15 G. De Burca, "EU External Relations: The Governance Mode of Foreign Policy", in B. Van Vooren. S. Blockmans and J. Wouters (ed) The EU's Role in Global Governance (Oxford: Oxford University Press (2012) 39 at 40.

${ }^{16}$ A. Bradford, " The Brussels Effect" Northwestern University Law Review 107 (2012) 1. 
global markets. Whether in the area of competition law, data protection of chemical safety standards, Bradford demonstrates that third countries are compelled to follow the regulatory template set by the EU - however stringent these may be - in order to maintain the ability to access the EU's lucrative market. In the Brussels effect, the EU's global regulatory power manifests itself as almost an accidental byproduct of the EU's economic power. But there is evidence that the EU is deliberately designing its regulations to govern the actions of persons and situations beyond its borders. For example, Scott has conducted a legal analysis of EU rules on climate change, air and transport services and financial services, demonstrating that the EU increasingly resorts to the practice of "territorial extension" "whereby its laws can apply to circumstances and conduct which take place abroad as long as jurisdiction is triggered by the establishment of a territorial connection.

A recent conceptual framework for the EU as a foreign policy power, developed by Damro, does away with the problematic debates concerning the substance and processes characterising the EU's external action by positing that the idea of a Market Power Europe whereby the EU's single market is identified as the EU's main source of power in international relations as well the most important means through which such power is exercised"s. Much like Normative Power Europe, the notion of Market Power Europe ascribes a sui generis identity to the EU, which it supposedly seeks to project abroad in the context of its foreign policy actions. However, contrary to Normative Power Europe, this identity is not based on a set of core norms and values but rather the prominence of a large regulated and integrated market. The distinction is significant as it means that although the EU remains a keen exporter of rules, it is not shackled to a closed set of substantive norms or values. For example, as Damro points out, whereas under Normative Power Europe, trade liberalization is linked to the core norm of liberty, under Market Power Europe, the EU can promote any policy or measure which reflect the preferences of the single market, including "market interventions via economic and social regulation"

At the root of this power is the magnitude of the single market. The EU is the biggest exporter of goods and services and the largest host of foreign investment in the world. The attractiveness of the market creates an incentive for States to converge their standards to those applied in the EU so as to reduce market access impediments

17 J. Scott, "Extraterritoriality and Territorial Extension in EU Law" American Journal of Comparative Law 62:1 (2013) 87.

18 C. Damro, "Market Power Europe" Journal of European Public Policy 19:5 (2012) 682 at 686.

19 Ibid. 
and also provides considerable leverage for the EU if it wishes to impose a particular regulatory position on third countries ${ }^{20}$. There is, furthermore, an institutional component to Market Power Europe. Because of its experience in large-scale market integration and regulation, the EU has over time developed a sophisticated institutional framework built to weigh up varying and often-conflicting interests in the adoption of policies and regulation. This "regulatory capacity" ${ }^{21}$ of the EU includes the ability to take into account the international dimension of regulatory measures (e.g., effect of EU rules on third countries, sanctions for non-compliance and interplay between domestic measures and international law $)^{22}$. Finally, the decision-making process underpinning the adoption of EU rules allows for the participation of non-state actors, which allows interest groups to play a significant role in the externalization of EU regulation. Damro contends that these three inherent features of the single market create a basis for the EU's identity as a market power ${ }^{23}$. In other words, the EU is ontologically prone to the externalization of EU market rules and policies, just as, under Normative Power Europe, the EU seems predisposed to project its normative foundations. However, the key difference is that, in Market Power Europe, there are no ethical or value based undertones to its external action. The EU's foreign policy goals do not depart significantly from those of traditional powers and they are certainly not understood by reference to its attachment to universal norms or values or a preference towards cooperative forms of action. Instead, it is a limitation - that is, its over-reliance on its economic power, that sets its apart from the rest.

3. WTO Dispute Settlement as a tool for the externalization of EU policy and rules

The EU has historically been one of the main proponents of the multilateral trading system. It played a pivotal role in the successful conclusion of the Uruguay Round negotiations that led to the establishment of the WTO and has, since, consistently pushed for the inclusion of further disciplines and the expansion of the organisation. One of the main reasons underlying the EU's preference for the WTO as a rule-setting forum is that it offers an adjudicatory system that can issue legally binding and enforceable ruling $\mathrm{S}^{24}$. In other words, the attractiveness of the WTO as a

\footnotetext{
${ }^{20}$ Ibid at 687.

${ }^{21}$ Ibid at 683 .

22 Ibid 687-688.

${ }^{23}$ Ibid at 698.

${ }^{24}$ D. De Bievre, "The EU regulatory trade agenda and the quest for WTO
} enforcement", Journal of European Public Policy 13:6 (2006) 851 at 854-855. 
regulatory forum can be attributed to the global reach of its rules as well as the fact that, unlike other fora, it offers credible and efficient dispute settlement and enforcement mechanisms ${ }^{25}$.

The importance attached by the EU to the WTO Dispute settlement Mechanism seems to fit neatly with the idea of a Civilian Power Europe or a Normative Power Europe keen to conduct a foreign policy within the confines of international law and institutions. Indeed, the EU is one of the most prolific litigators in the WTO and has one of the best track records in terms of compliance with WTO rulings ${ }^{26}$. However, the EU's compliance with WTO rules can, to a large extent, be explained by the fact that was one of the main architects of the multilateral trading system, WTO rules tend to reflect its own approach to market regulation. And whilst a number of studies have shown that although the EU does make efforts to ensure that its laws are WTO compliant, the fear of adverse rulings is not always at the forefront of the minds of EU decision makers when considering whether to adopt a piece of legislation ${ }^{2}$. In other words, whilst the EU portrays itself as a promoter of international law and effective multilateralism, it is certainly not averse to going it alone in order to pursue its interests or safeguards its preferences.

However, this strand of research has focused on the impact of WTO law and rulings on the decision-making processes of EU regulators. Curiously, less research has been undertaken to assess the extent to which the EU uses the WTO dispute settlement mechanism to spread the reach of its influence abroad. Yet, there is increasing evidence that policy makers in Brussels see the WTO's adjudicatory system as an important tool to promote its interests and regulatory positions abroad. This is best exemplified by the European Commission's 2006 Communication, "Global Europe: Competing in the world" ("Global Europe strategy") ${ }^{28}$ which

25 Ibid.

${ }^{26} \mathrm{~A}$. Young, "Less than what you might think: The impact of WTO rules on EU policies", in O. Costa and K. Jorgensen (eds.) When Multilateralism hits Brussels: The Influence of International Institutions on the EU (London: Palgrave MacMillan (2012)), 23 at 40.

27 Ibid, at 36; F. De Ville, "European Union regulatory politics in the shadow of the WTO: WTO rules as a frame of reference and rhetorical device" Journal of European Public Policy 19:5 (2012) 700-718.

${ }^{28}$ Communication from the Commission to the Council, the European Parliament, the European Economic and Social Committee and the Committee of the Regions GLOBAL EUROPE: COMPETING IN THE WORLD A Contribution to the EU's Growth and Jobs Strategy COM/2006/0567 final. 
outlined the framework for the EU's trade policy in the aftermath of the collapse of the WTO Doha Round Negotiations. This policy statement is significant in that it signalled a shift away from the EU's focus on multilateral negotiations and set out the EU's intent to pursue an aggressive trade policy whereby all avenues would be explored to pry open lucrative foreign markets. This includes, inter alia, the negotiation of comprehensive free trade agreements, the adoption of unilateral measures, the establishment of cooperative arrangements (e.g., trade dialogues) and, saliently, the use of the WTO dispute settlement mechanism to enforce the EU's rights whenever possible. The approach is explained by Damro as follows:

"[T]he EU may bring an offending foreign non-tariff barrier before the World Trade Organization's (WTO) Dispute Settlement Mechanism (i.e., negative tool). By doing so, the EU undertakes an intentional effort at externalizationan attempt to get the target WTO member(s) to comply with international trade rules in a way that generally satisfies or conforms to the EU's marketrelated policies and regulatory measures. Bringing a foreign regulatory measure or any perceived violation of international trade rules to the WTO's Dispute Settlement Mechanism is a clear instance of the EU using coercion to adjust the behaviour of other actors in the international trading system.

The WTO dispute settlement mechanism is therefore one of the many tools used by the EU to influence the regulatory policies of others. The EU uses WTO litigation as a means to coerce States to revise domestic regulations in line with its own regulatory positions. Moreover, as shown by Krueger, the EU is a strategic WTO litigant that uses the WTO dispute settlement mechanism "to shape WTO governance" ${ }^{\prime 2}$. The EU will launch or participate in disputes - that are in some cases of little relevance to it - in order to influence and set the rules of international trade by putting forward an interpretation of WTO law that promotes its long-term interests.

4. WTO Dispute Settlement as a means to export the EU

${ }^{29}$ T. Kruger, Shaping the WTO's Institutional Evolution: The European Union as a Strategic Litigant in the WTO, in: D. Kochenov, F. Amtenbrink (eds.), The European Union's Shaping of the International Legal Order, (Cambridge: Cambridge University Press (2013)) 169 at 171. 
The following section examines two case studies that illustrate how the EU uses the WTO dispute settlement mechanism and, in some cases, incorporates WTO litigation into its own domestic policy and regulatory frameworks, to project its interest and norms abroad. The first case study concerns the EU's current external policy designed to ensure access to exhaustible mineral resources - a policy that expressly identifies WTO litigation as a route to achieve its objective and which has resulted in two challenges being brought against trade restrictive measures adopted by China with respect to raw materials and rare earths. The second subsection examines the EU's current regulatory regime banning trade in seal fur produced under inhumane conditions which was, itself, the subject of a recent challenge before the WTO. Through these cases, it will be shown that the EU sees WTO dispute settlement as a means to secure its objectives and promote its own values and norms, and that the use of the WTO dispute settlement mechanism does not reflect an attachment to or preference for the multilateral process, rather that the EU will assess all available policy options available to it (e.g., unilateralism, cooperation, WTO dispute settlement) and opt for the one that one which is more likely to successfully achieve its objectives.

\subsection{The EU's Mineral Resources Policy}

\subsubsection{EU Raw Materials Initiative}

The increasing volatility of commodity prices caused by the growing influence of finance as well as the surge in demand for already scarce mineral resources from emerging economies led the EU to develop its Raw Materials Initiative (RMI) - an integrated strategy designed to secure sustainable access to nonenergy and non-agricultural raw materials. The 'raw materials' covered by the RMI are metals and minerals that are typically sourced from specific geographical locations, have few substitutes and are used for the manufacture of high-technology products and in the environmental sector and have few substitutes ${ }^{*}$. Together, these factors mean that the countries producing such materials can successfully control global prices by limiting production or exports. This is effectively what occurred in 2007-2008, where the application of export restraints (whether in the form of tariffs, export taxes or quantitative restrictions, or minimum purchase prices) by producers

$30 \mathrm{~J}$. Korinek, and K. Jeonghoi, "Export restrictions on strategic raw materials and their impact on trade and global supply." OECD Trade Policy Studies The Economic Impact of Export Restrictions on Raw Materials 2010 (2010) at 104. Retrieved 28 April 2015 www.oecd.org/tad/ntm/43934153.pdf. 
of raw materials - and, in particular, China-led an exponential increase in prices of raw materials ${ }^{3 .}$.

The EU's external trade policy has thus become a key component of the RMI which it aims to ensure market access for European manufacturers to the raw materials on which they are critically dependent. This policy is based on three pillars: (i) 'setting the rules of the game' by imposing trade disciplines on export restrictions in the context of bilateral or multilateral trade negotiations; (ii) 'enforcing the rules of the game' by dispute settlement in order to remove barriers to access to raw materials; and (iii) 'reaching out to third countries' by establishing bilateral dialogues (notably in the context of the OECD). The first two pillars are complementary. The EU negotiates the inclusion of disciplines on export restraints in trade agreements and then seeks the enforcement of such disciplines by using dispute settlement mechanisms, where available, or applying unilateral trade defense measures. The first pillar has led to the conclusion of various bilateral trade agreements as well as WTO accession agreements which have included prohibitions on export restraints (e.g., duties, taxes or measures of an equivalent effect on exportation) ${ }^{2}$.

China has been the one of the main targets of the RMI. It is a mineral resource rich country that has strategically used export restraints to create a competitive advantage for domestic downstream producers who rely on raw materials ${ }^{3}$. This has been achieved, on the one hand, by restricting the supply of raw materials to foreign firms which, increases global prices and therefore undermines the ability of foreign firms to compete ${ }^{3}$ and, on the other hand, by ensuring that Chinese state-owned enterprises and domestic producers have access to raw materials at below market prices. ${ }^{35}$ With respect to China, to the extent that a trade agreement remains an

${ }^{31}$ M. Bronkers and K. Maskus, "China - Raw Materials: a controversial step towards evenhanded exploitation of natural resources" World Trade Review 13(2) (2014) 393 at 394.

32 European Commission, "EU Trade Policy for Raw Materials Second Activity Report", 30 May 2012, p.10-14. Retrieved 28 April 2015 http://ec.europa.eu/trade/policy/accessing-markets/goods-and-services/rawmaterials/

${ }^{33}$ B. Karapinar, “China's export restriction policies: complying with 'WTO plus' or undermining multilateralism" World Trade Review 10(3) (2011) 390 at 401.

${ }^{34}$ A. Willems and S. De Knop, "The EC and US WTO challenge to China's export restrictions: will it increase their downstream industries' competitiveness?" International Trade Law and Regulation (2009), 171 at 172.

$35 \mathrm{M}$. Du, "China's state capitalism and world trade law" International \& Comparative Law Quarterly 63(2) (2014) 411 at 425. 
unlikely prospect in the short to medium term, the RMI has materialized mainly though two WTO disputes involving export restraints.

\subsubsection{Raw Materials and Rare Earths disputes}

The EU has launched two separate complaints against China regarding various export restraints on the exportation of certain mineral resources. In the first of these disputes, China - Measures relating to the Exportation of Various Raw Materials ("Raw Materials")", the EU, along with the United States and Mexico, lodged a complaint in 2009 against the application of quotas, export duties, minimum export prices on raw materials such as bauxite, coke, fluorspar, magnesium and manganese as well as additional requirements and procedures that must be fulfilled by exporters of such materials. The second dispute, China-Measures relating to the exportation of rare earths, tungsten and molybdenum ("Rare Earths") concerned export restraints relating to so-called "rare earths" - 17 metals with specific chemical, magnetic and fluorescent properties and used in the manufacture of high technology goods such as telephones, computers and televisions ${ }^{3}$. In both cases, China has argued that the export restrictions were needed in order to manage what are non-renewable and rapidly dwindling natural resources. China holds the largest national reserve of rare earths accounting for approximately $9.5 \%$ of global supply, and has argued that at the current rate of exploitation its supply of rare earths will be exhausted within 30 years. Based on this, it has adopted a number of policies designed to reduce the production of rare earths in a manner that would not adversely impact its domestic industry ${ }^{3 .}$.

The export restrictions imposed by China were challenged on various grounds. Firstly, the complainants claimed that the quotas and minimum export prices violated a number of GATT obligations, most notably, Article XI GATT requiring all WTO Members to eliminate prohibitions and quantitative restrictions on exports. Secondly, it was claimed that the imposition of export duties on raw materials covered by the dispute was inconsistent with Article 11.3 of China's

36 Panel Report, China - Measures Related to the Exportation of Various Raw Materials, WT/DS394/R, 5 July 2001; Appellate Body report, China Measures Related to the Exportation of Various Raw Materials, WT/DS394/R, 30 January 20012.

37 Supra footnote 30 at 117.

38 Supra footnote 30 at 118. 
Protocol of Accession", which requires it to eliminate all taxes and charges applied to exports except with regard to products specifically listed in annex 6 of said protocol. Although China accepted that it had violated WTO rules, it argued that such measures could be justified on two grounds. With regard to export quotas, China invoked its right under Article XI GATT to temporarily apply quotas in order prevent or relieve critical shortages. The exception applies specifically to circumstances where it is established that there is a significant shortage or the likelihood of a significant shortage of a product that is essential for the exporting country. However, the argument was rejected by both the WTO Panel and the Appellate Body since the progressive depletion of an exhaustible resource was not deemed consistent with the notion of a 'critical shortage'to, and the restraints had been in place for too long (in some cases more than a decade) to be considered temporary ${ }^{* 1}$.

China further argued that the export restraints could be justified under Article XX GATT, insofar as they constituted measures relating to the conservation of exhaustible natural resources ${ }^{\text {n}}$ or because they were necessary to protect human, animal, or plant life or health ${ }^{\text {s. }}$. This line of defense raised two questions. Firstly, with regard to the export duties, it was unclear whether general exceptions under Article XX GATT could be invoked in the context of WTO plus commitments made in the context of accession protocols. Previously, in China-Audiovisuals, the Appellate Body had ruled that restrictions on the importation of cultural goods violating the commitment under paragraph 5.1 of the Protocol to ensure the right to trade in all goods throughout its territory could be justified on the basis of Article XX GATT because the aforementioned paragraph 5.1 specifies that the right to trade that China committed to is "without prejudice to China's right to regulate trade in a manner consistent with the WTO Agreement" ${ }^{\prime}$. However, in both China - Raw Material and China-Rare Earths, the Appellate Body found that Article XX general exceptions could not be made available to China since Paragraph 11.3 of the Protocol on taxes and duties to applied to imports or exports lacked any reference to Article XX GATT as well as any language relating to the China's right to regulate 'right to regulate'. Secondly, with regard to the export quotas applied by China, which were not

39 WTO, Accession of the People's Republic of China, 23 November 2001, WT/L/432.

40 China - Raw Materials, Paragraph 336.

${ }^{41}$ Ibid, Paragraph 340.

42 Article XX(g) GATT.

${ }^{43}$ Article XX(b) GATT.

44 Paragraph 5.1 Protocol of Accession. 
covered by the Accession Protocol, China argued that these were intended to ensure the conservation of exhaustible natural resources and therefore could be justified under Article XX(g) GATT. Both the Panel and the Appellate Body rejected the defense because China was not able to demonstrate that the concerned measures were "made effective in conjunction with restrictions on domestic production or consumption" ${ }^{45}$. Because the export quotas were not accompanied by similar restrictions for domestic producers, it was found that such measures were not designed to address conservation concerns but rather to provide domestic producers an advantage against their competitors.

The RMI related disputes are clear examples of how WTO litigation is deliberately being integrated within EU policy frameworks as a means to externalize its interests. Through the China-Raw Materials and the China-Rare Earths, the EU, along with other WTO Members, was able to force China to comply with the terms of the Accession Protocol, allowing it to secure market access to goods which it would otherwise not have secured by resorting to unilateral action or even by engaging in cooperative processes. Indeed, no bilateral trade agreement is currently envisaged between the EU and China and, in the context of the bilateral dialogue established by the EU with China, the evidence so far is that little progress has been made in terms of establishing common ground on issues pertaining to raw materials." In this sense, the place of pride occupied by WTO dispute settlement in the context of the RMI reflects in part the inability of the EU to effectively wield its market power against China.

\subsection{Seal Products Trade Ban}

\subsubsection{EU Seal Trade Regulation}

The plight of seals has been an ongoing concern for animal activists within the EU for the better part of the last fifty years. Whilst a EU-wide ban on the import of seal pups furs and fur skin products had been in place since 1983, this regulation was not thought to have gone far enough by certain Member States who decided to

45 Paragraph 5.2.2-5.2.9 Appellate Body Report Rare Earths.

46 European Commission, "EU Trade Policy for Raw Materials Second Activity Report", 30 May 2012 at 18. Retrieved on 28 April 2015 http://ec.europa.eu/trade/policy/accessing-markets/goods-and-services/rawmaterials/. 
impose national bans on trade and processing of all seal products". The proliferation of such national bans undermined the uniformity of the EU's external trade regime and led the EU to enact a regulation banning trade in seal products. In 2009, the EU adopted the Regulation No $1007 / 2009 *$ on trade in seal products prohibiting the placing on the market and the import or export of all seal products (Regulation). Three exceptions to the prohibition are specified under the Regulation and then further elaborated under the Commission Regulation No No 737/2010 (Implementing Regulation) laying down detailed rules for the implementation of the Regulation. They permit the placing on the market of seal products from hunts traditionally conducted by the Inuit and other indigenous communities (IC exemption), from hunting regulated under national law and conducted for the sole purpose of the sustainable development of marine resources; which have been imported by travellers or their families for non-commercial reasons.

By the EU's own admission the regulation was not adopted to ensure the conservation of an endangered species since the world seal population has steadily increased over the years. Rather, the ban sought to protect and promote European values regarding animal welfare and, in particular, to reflect the abhorrence generally felt by the EU population towards products derived from seals killed under inhumane conditions ${ }^{5_{0}}$. The Regulation was based on a scientific opinion delivered by the European Food Safety Authority, which found that the regulatory and management systems for seal hunting varied significantly from one State to another and that there was evidence that in in some cases the manner in which the killing is practice "causes avoidable pain, distress and other forms of suffering"

The overarching aim pursued by this internal legislative measure is to discipline the regulatory environment and practices of non-EU States involved seal

47 R. Howse and J. Langille, "Permitting Pluralism: The Seal Products Dispute and Why the WTO Should Accept Trade Restrictions Justified by Noninstrumental Moral Values" Yale J. Int'l L. 37 (2012) 367 at 374-377

48 Regulation No 1007/2009 of the European Parliament and of the Council of 16 September 2009 on trade in seal products) OJ L 286, 2009 at 3639.

${ }^{49}$ Commission Regulation No 737/2010 of 10 August 2010 laying down detailed rules for the implementation of Regulation (EC) No 1007/2009 of the European Parliament and of the Council on trade in seal products OJ L 216, 2010 at $1-10$

${ }^{50}$ Recitals 4 and 5 of Regulation No 1007/2009.

51 European Food Safety Authority Animal Welfare aspects of the killing and skinning of seals - Scientific Opinion of the Panel on Animal Health and Welfare, 19 December 2007, The EFSA Journal (2007) 610 at 9. 
hunting: access to the EU's internal market is made contingent upon compliance with established standards relating to the effective killing of seals. This is a clear illustration of how the EU acts as a market power, using the size of its internal market to trigger regulatory reform in third countries wishing to do business in the EU. It also reinforces the idea that, rather than having a preference towards cooperative processes in international relations, the EU will readily pursue the unilateral route where this option is more amenable to its immediate interests. For example, in the impact assessment conducted in 2008 on the impact of the trade ban on seal products, the European Commission considered the possibility of concluding bilateral and multilateral agreements to promote higher animal welfare standards as an alternative to an outright ban. At the time, this option may have appeared preferable, as the EU was about to initiate negotiations on an important trade deal with Canadas, the largest seal-hunting nation and the one which stood most to lose from the ban. An outright EU ban on trade in seal products was not viewed kindly by Canada, which had made no secret of its intention to challenge any such measure before the WTO dispute settlement body - and may have scuppered the negotiations on a bilateral trade agreement. However, because of the importance attached to securing access to the EU's internal market (the EU is Canada's second largest trading partner), the EU felt fairly secure in its assumption that the unilateral imposition of an added regulatory burden on Canada would not be sufficient to cause the collapse of negotiations ${ }^{s}$. Therefore, the EU had no qualms in resorting to unilateral action to force regulatory reform abroad since, in addition to being the most effective way of achieving its aims, this option would not cause any significant adverse impact to the European economy.

\subsubsection{EU-Seal Products dispute}

Canada and Norway challenged the Regulation arguing, inter alia, that the exemption of hunts conducted by Inuit and other indigenous communities from its scope violated Articles I (most favoured nation obligation), III (national treatment obligation and XI GATT (elimination of quantitative restrictions) as it de facto

52 The EU- Canada Comprehensive Economic and Trade Agreement (CETA) concluded in September 2014. Yet to be approved by the EU Council of Ministers and the European Parliament. Text retrieved 28 April 2015 http://ec.europa.eu/trade/policy/in-focus/ceta/.

53 Euractiv, 2009. 'Canada vows to challenge EU seal products ban', 28 August 2009. Retrieved 28 April 2015 http://www.euractiv.com/trade/canadavows-challenge-eu-seal-pr-news-222348.

${ }^{54}$ F. De Ville, "Explaining the Genesis of a Trade Dispute: the European Union's Seal Trade Ban”, Journal of European Integration 34(1) (2012) 37 at 49. 
discriminated against Canadian and Norwegian seal products: This was because whereas Inuit and other indigenous communities represented the vast majority of seal hunters in Greenland, such communities comprised a small fraction of sealers in Norway and Canada. The IC exemption was designed and implemented in such a way as to ensure that all Greenland sealers were permitted to place their products in the EU internal market, whilst excluding the majority of Canadian and Norwegian sealers.

The EU had anticipated this challenge and specifically addressed the WTO compatibility in the Impact Assessment which preceded the adoption of the Regulation:

An import ban can be justified on the basis of the general exceptions contained in Article XX of the General Agreement on Trade and Tariffs (GATT), more specifically by invoking Article XX (a) under which the adoption or enforcement by any contracting party of measures necessary to protect public morals (i.e "standards of right or wrong conduct maintained by or on behalf of a community or a nation") is allowed provided that such measures are not applied in a manner which would constitute a means of arbitrary or unjustifiable discrimination. The proposed measure is not discriminatory, as the various prohibitions to be provided for will apply to intra-Community trade as well as to imports and exports. ${ }^{56}$

The key question thus addressed successively by the WTO Panel and Appellate Body concerned whether the ban could be justified under the public morals exception of Article XX(a) GATT. In order to do so, the EU had to demonstrate that the ban was designed to protect public morals, that it was necessary to achieve these objectives and that it satisfied the requirements under the Article XX GATT chapeau prohibiting measures the measure from being arbitrary, unjustifiable, or a disguised restriction on international trade. In casu, both the Panel

55 Panel Report, EU-Measures Prohibiting the Importation and Marketing of Seal Products WT/DS400/AB/R 25, November 2013; Appellate Body report, EU-Measures Prohibiting the Importation and Marketing of Seal Products WT/DS400/AB/R, 22 May 2014.

${ }^{56}$ European Commission, "Impact Assessment on the potential impact of a ban on products derived from seal species" COM(2008) 469 final at 53. Retrieved 28 April 2015 http://ec.europa.eu/environment/biodiversity/animal_welfare/seals/seal_hunti ng.htm 
and the Appellate Body sided with the EU's contention that the ban could be justified under Article XX(a). Firstly, with regards to the question of whether the protection of seal welfare was a legitimate public moral concerned covered by Article XX(a) GATT, the Panel found that that the "concept of public morals is a relative term which needs to be defined based on the standard of right and wrong in a given society" ${ }^{\prime \prime}$ and, that in the particular context of this dispute it had been established that "the concerns of the EU public on animal welfare involve standards of right and wrong within the European Union as a community" ${ }^{\prime s}$. Secondly, the Panel agreed that the ban was necessary to protect public morals insofar as was deemed "capable of making and does actually make a contribution" to the achievement of addressing public moral concerns as it "prevents to a certain extent the EU public from being exposed to and participating as consumers in commercial activities related to the products derived from seals that may have been killed inhumanely [and] also appears to have the effect of negatively impacting the global demand for seal product". However, it was also found that the EU seals regime failed to satisfy the requirements under the chapeau of Article XX GATT chapeau since the discrimination entailed in the IC and MFM exemptions were found to be arbitrary or unjustifiable. For example, that the panel rejected that the regulatory distinction operated between commercial and IC hunts in Greenland, because, in practice, the manner in which Inuit hunts were conducted in Greenland bore all the hallmarks of large scale commercial hunts.

In sum, although certain elements of the Regulation and the Implementing Regulation (e.g., IC exemption) were found to violate WTO law, the EU-Seal Products ruling confirmed that the trade ban itself could be justified because it sought to protect public morals commonly held by the EU's population. In doing so, the ruling recognized the importance of pluralism and the right of WTO Members to regulate in accordance with their particular value systems which, given the wide membership of the organization, can vary significantly from one country to anothers. Clearly, EU - Seal Products can be seen as an evidence of the WTO's deference towards the regulatory and cultural diversity that characterizes its membership trade restrictive measures may be adopted so long as they genuinely reflect cultural values, even where these are not necessarily shared by other WTO Members ${ }^{\infty}$. It is somewhat ironic then that the upshot of a ruling intended to recognize regulatory

57 EU-Seal Products paras 5.194-5.201

${ }^{58}$ EU-Seal Products para 7.5

${ }^{59}$ R. Howse and J. Languille, supra footnote 47 at 237-430.

60 Ibid at 428-429. 
diversity is to allow the EU to unilaterally disseminate its regulatory positions abroad. The primary objective of the EU seal ban may have been to ensure that European consumers are not faced with products derived from seals killed under inhumane conditions, but it is also designed to strong-arm third countries that wish to continue selling seal products in the lucrative EU internal market to change their regulatory systems in accordance with the EU's domestic preferences. Indeed, even before bringing the case before thw WTO's judicature, Canada had taken steps to reform its seal hunt laws to ward off the threat of the EU trade ban'.

The regime thus illustrates a particular manifestation of what Scott refers to as the 'international orientation' of EU lawmaking and its approach to norm exportation - the EU enacts laws, which require compliance with its own standards in order to extend market access to third countries, but ensures that such unilateralism is consistent with international law ${ }^{2}$. The EU Seal Regime may have been primarily driven by strong domestic political preferences but by anticipating the possibility of a WTO challenge and by designing the relevant regulations in line with WTO law, the EU has sought to ensure that the external repercussions of these regulations are not undermined by adverse WTO rulings. In this sense, rather than being a constraint on regulatory autonomy, WTO law furthers the EU's policy agenda and, in particular, external policy objectives pursued by EU domestic legislation.

\section{Questioning the distinctiveness of the EU as an international actor}

Both the RMI and the EU ban on trade in seals can be used as examples of the how the EU acts as a normative power. In both cases the EU has a devised policy or regulatory framework which is intend to promote certain foundational normative values abroad. With regard to the RMI, the goal of securing market access to key mineral resources can be linked to the EU's attachment to economic freedoms that underpin the functioning of the internal market. The EU trade in seals ban intends to protect and promote EU environmental standards and, more generally, sustainable development goals. Furthermore, the reliance on the WTO dispute settlement mechanism and the efforts undertaken by EU legislators to ensure WTO compliance of EU domestic legislation underlines the EU's commitment to the rule of law and

61 Bridges Weekly. "Canadian Delegation in Brussels to Stop Proposed Seal Ban” Bridges Weekly 13(3) 28 January 2009. Retrieved 28 April 2015 http://www.ictsd.org/bridges-news/bridges/news/canadian-delegation-inbrussels-to-stop-proposed-seal-ban.

$62 \mathrm{~J}$. Scott supra footnote 17 at 114. 
international law and institutions. These two examples also reflect key elements of Market Power Europe. It is most evident in the context of the EU Seal regime where the EU, firstly, used the threat of the removal of market access as a tool to influence the behavior of third countries and, secondly, where benefitted from its significant regulatory capacity to assess the international dimension and external implications of the projected regulatory framework. Prior to the enactment of the regulations establishing the EU trade in seals ban, the EU assessed the various options available to it - unilateralism, bilateralism and multilateralism - and opted for unilateral action because it was deemed the most effective course of action. Indeed as the third countries targeted by the regime are heavily dependent on access to the EU's internal market, the EU could use market access as leverage to secure the type of regulatory reforms it was seeking from such countries. In other words, there was no preference towards multilateral cooperation; where the EU's market power is sufficient to achieve its aims, the EU is not averse to going it alone as long as this suits its immediate interests. In addition, the EU anticipated the inevitability of a challenge before the WTO and addressed the issue of WTO compatibility by ensuring that its regulations were largely non-discriminatory and that the trade restrictions could be reasonably justified under the GATT general exceptions provisions. But features of Market Power Europe can also be identified with respect to the RMI. When developing this policy framework, the EU understood that an economic powerhouse such as China was unlikely to be concerned by any decision by the EU to bar access to its market. The decision of EU policy makers to rely on WTO law and institutions reflects an acceptance that, as far as China is concerned, the exercise of market power would be a pointless exercise.

The above considerations demonstrate that whilst conceptualisations such as Normative Power Europe and Market Power Europe are useful tools to understand the EU's role international actor, they do not represent, on their own, allencompassing theoretical frameworks explaining the EU's external action. This brings us back to the question whether there is anything fundamentally distinctive in the manner that the EU seeks to exert power in international relations when compared to traditional foreign policy powers such as the US. The supposed 'exceptionalism' of the US, the conviction that the norms and values espoused by the US should be held as a model by for the international community, could easily also apply to the EU. The idea of Normative Power Europe itself is based on the premise that the EU sees itself as a regulatory model to be emulated by others and Market Power Europe accepts that the EU seeks to export its standards abroad in order to, inter alia, facilitate the ability of EU forms to access foreign markets. A counter- 
argument to the contention of the EU's exceptionalism would be that the values promoted by the EU are universal and, even if tainted by self-interest, they seek to benefit the entire international community as a whole ${ }^{\text {. }}$. However, as the EU-Seals dispute demonstrates, this argument does not stand up to scrutiny. The EU's values are not necessarily shared by all, but rather reflect its historical cultural and political preferences. In fact, as shown by Bradford and Posner, a consistent and defining characteristic of exceptionalist States is that they seek to pass off norms reflecting domestic preferences as universal norms ${ }^{A}$. This is achieved by influencing the development of international law in the context of treaty negotiations as well as pursuing compliance with international law in accordance their preferences. Bradford and Posner convincingly argue that the EU routinely pursues domestic policy preferences in the context of international institutions such as the WTO. This is in line with the views of other international relations scholars, such as Young, who have posited that the EU's attachment to the multilateral trading system can be explained by the fact that the rules of the WTO reflects its own values and interests ${ }^{\star}$. A notable and recent example is the negotiation of WTO plus rules in China's Accession Protocol, which significantly restrict China's regulatory autonomy, and has allowed the EU - amongst others - to secure market access to Chinese raw materials. And at the stage of compliance, the EU-Seals dispute is an ideal case study of how the EU uses the WTO dispute settlement mechanism to promote interpretations of WTO law that embody its values.

A defense of the EU against possible accusations of 'exemptionalism' in the sphere of WTO law is perhaps on surer ground. In both the RMI disputes the EU challenged Chinese measures that clearly violated WTO law and in the EU-Seals dispute, the EU took care to ensure that internal regulation reflecting domestic political preferences were broadly WTO compliant. The overwhelming evidence suggests that the EU has a positive record as far as WTO compliance is concerned ${ }^{\text {* }}$. Here again, it must be pointed out that compliance is to a large extent a byproduct of

63 A. Van den Hooven, "Regulatory capitalism and multilateral trade". In S. Lucarelli and I. Manners (eds.) Values and Principles in European Union Foreign Policy (Oxford: Routledge (2006) 185 at 198; I. Manners \& T. Diez, "Reflecting on Normative Power Europe". In F. Berenskoetter, \& M. J. Williams (Eds.), Power in World Politics. (New York: Routledge (2007)) 173 at 181.

64 Supra footnote 14 at 53.

65 Supra footnote 14 at $14-23$.

${ }^{66}$ A. Young, supra footnote 26 at $123-124$.

${ }^{67}$ B. Wilson, "Compliance by WTO Members with Adverse WTO Dispute Settlement Rulings: The Record to Date" Journal of International Economic Law 10(2) (2007) 397-403; A Young, supra footnote 26 at 23. 
the fact that WTO reflects the norms, values and interests of the EU. Even so, in the few instances where EU measures have been found to violate WTO law, there are cases where the EU has chosen against compliance where this would run counter to its immediate interests ${ }^{\text {s. }}$. Overall, the foregoing paints a picture of the EU that corresponds to that of the stereotypical exemptionalist: an international actor that shapes and enforces the rules of the international legal system but seeks "to insulate itself from the domestic blowback of [...] the multilateral instruments it has created"

All this, of course, is not to say that the EU's modus operandi as an international trade actor is identical to that of other international actors. As discussed above, the norms and values promoted by the EU in the WTO are in many instances specific to it. Likewise, the sui generis nature of the EU's regulatory process means that it is better placed than most to design measures that not only comply with international law but also contribute to the furtherance of the EU's foreign policy goals. In this respect, the two case studies examined in this paper have put the spotlight on a particularly interesting feature of the EU's role in shaping WTO law that is, that the potential for WTO litigation is increasingly taken into account by the EU in the process of developing policies and regulatory measures as a tool to export EU interests, norms and values. These features of the EU's external action, in realm of the international trading system, however novel, reflect shared values amongst EU Members States as well as the institutional specificities of the EU's regulatory processes.

\section{Conclusion}

This article has examined the EU's relationship with the WTO - and more specifically its approach to WTO litigation - to debunk identity narratives, such as Normative Power Europe, that present the EU as distinctive foreign policy actor ontologically predisposed to project of universal norms or values and to eschew coercion or unilateralism in favour of cooperative forms of action. The EU was a major force behind the conclusion of the WTO agreements and has subsequently shaped the evolution of its rules in the context of the negotiation of WTO accession agreements as well as through its participation in WTO litigation. In doing so, the EU has ensured that the WTO represents a legal order that reflects the EU's foreign policy objectives. However, whether it is in securing old-fashioned free trade imperatives of opening foreign markets or disseminating rules, these objectives

68 Ibid at 23-41.

${ }^{69} \mathrm{~J}$. Ruggie, supra footnote 1 , at 6. 
remain very much Euro-centric and do not necessarily underpin any form of attachment towards universal norms and values. In the same vein, although the EU does appear to be committed to cooperation in the context of its international relationships, the strength of this commitment will vary from one case to another depending on its interests. The EU has put the WTO at the forefront of its policy designed to open foreign markets for mineral resources because it knows it has little leverage against the key producers of such commodities. Conversely, with respect to its ban on products derived from seal hunts, the EU carefully scrutinized the various policy options available to it (which included the possibility of negotiating agreements with States currently engaged in seal hunting practices) but opted for a unilateral action because its significant economic leverage over the offending countries would be the most effective way of forcing their hand.

The source of the EU's power - its reliance on economic or 'market' power is the only truly distinctive aspect of its power. However, the reliance on its market and regulatory power is not the result of a choice but purely reflects the fact that as a supranational organization based on economic integration, the EU's internal market remains its most effective tool to exert influence abroad. In this sense the use of market power is purely the byproduct of the EU's own internal limitations. Beyond this, there is fundamentally nothing that is inherently unique about the EU's external trade action. It attempts to protect and promote its interests by shaping the international community and legal order in its own image. This is the archetypal modus operandi of great foreign policy powers - the desire to set the rules of the game in a manner that both promote your values and interests whilst, simultaneously, shielding that power from the adverse consequences of such rules. The manner in which the power is exercised is also indistinctive. The EU is pragmatic in its choice of tools. It will use existing international fora to pursue foreign policy goals when this suits its interests, but will also readily pursue other options that may be more effective in securing those interests. 